BONAFIDE: Jurnal Teologi dan Pendidikan Kristen

www.jurnal.sttissiau.ac.id/Volume 1/Nomor 2/Desember 2020/hal. 218-233

\title{
IMPLEMENTASI PENDIDIKAN AGAMA KRISTEN DALAM KELUARGA MELALUI GEREJA
}

\author{
Elena Saba, Ezra Tari, Rita \\ Institut Agama Kristen Negeri Kupang \\ email korespondensi: tariezra@gmail.com
}

\begin{abstract}
The church's role in implementing Christian Education (CE) still lacks because there is hatred in the family. This research aims to cultivate attention, motivation, and attitudes to improve human relations; and refine feelings to love and care for one another. The research subjects were the Talenalain Rayon 5 Congregation, the Gereja Masehi Injili di Timor(GMIT). The method used is qualitative. The data were collected using interview techniques, and the results were presented in a narrative form. The results showed that parents realized that CE is the most important learning in the family. The church has not maximally become a place for collective learning that has built to a Christian family. CE is still limited to worship, the celebration of church holidays, teaching through family participation in the fellowship, teaching through pastoral activities to Christian families.
\end{abstract}

Keywords: Church, Christian Education, Family

\begin{abstract}
Abstrak. Peran gereja menerapkan pendidikan agama Kristen masih sangat kurang karena ada kebencian dalam keluarga. Tujuan penelitian ini yakni berusaha menumbuhkan perhatian, motivasi dan sikap untuk memperbaiki hubungan antar manusia; serta menajamkan kembali perasaan untuk saling mengasihi dan mempedulikan. Subyek penelitian adalah Jemaat Talenalain rayon 5, Gereja Masehi Injili di Timor (GMIT). Metode yang dipakai adalah kualitatif. Data diambil dengan teknik wawacara dan hasilnya dipaparkan dalam bentuk narasi. Hasil penelitian menunjukkan bahwa orang tua menyadari bahwa PAK adalah pembelajaran paling penting dalam keluarga. Gereja belum maksimal menjadi wadah belajar bersama yang melahirkan keluarga yang berwatak kristiani. Pendidikan Agama Kristen masih sebatas ibadah bersama, perayaan hari raya gereja, mengajar melalui partisipasi keluarga dalam persekutuan, mengajar melalui pastoralpastoral kepada keluarga Kristen.
\end{abstract}

Kata kunci: Gereja, Pendidikan Agama Kristen, Keluarga

\section{PENDAHULUAN}

Keluarga merupakan sel terkecil di dalam jemaat dengan masyarakat.

Keluarga merupakan institusi awal tempat berlangsungnya cara belajar anak dalam menyikapi realitas dengan kondisi atmosfer pembelajaran.(Wahy 2012) Pola membimbing bisa terjadi dengan pola interaksi antara anak dengan orang tua yang 
BONAFIDE: Jurnal Teologi dan Pendidikan Kristen

www.jurnal.sttissiau.ac.id/Volume 1/Nomor 2/Desember 2020/hal. 218-233

meliputi keingintahuan secara intelektual, dan norma-norma yang berlaku di masyarakat.(Subianto 2013)

Pembelajaran Agama Kristen bertanggung jawab untuk berbenah diri dalam berinteraksi dengan teknologi digital dengan tetap menjaga komunikasi dengan gesekan manusiawi yang relatif sedang dibutuhkan dalam melaksanakan pembinaan serta perawatan kepercayaan.(Harmadi dan Jatmiko 2020) Dengan kata lain, Pendidikan Kristen tidak saja terbatas kepada pendidikan atau pengajaran Pendidikan Agama Kristen (PAK) di sekolah, tetapi mencakup pendidikan di dalam keluarga serta warga jemaat.(Andrianti 2012)

Gereja dalam pembelajaran nasional seyogyanya peran aktif bertanggung jawab ikut serta dalam peningkatan kualitas guru menjadi profesional. Gereja ada untuk menolong guru dalam perkembangan rohani.(Darmawan 2014) Sebagai salah satu tugas gereja, PAK memiliki tanggung jawab pendidikan yang memiliki keunikan dibanding dengan pendidikan lain, yaitu tetap membimbing peserta didik dalam perspektif kekristenan dan memberikan pedoman pandangan dunia kekristenan dalam memandang, memperhitungkan, dan berinteraksi dengan dunia hari ini.(Eliasaputra, Novalina, dan Siahaan 2020)

Keluarga Kristen merupakan tempat mengarahkan kepercayaan pada kanak-kanak. Sebagian perihal yang perlu dicoba oleh keluarga Kristen untuk menjadikan keluarganya pusat bermisi yang menghasilkan keluarga menyebarkan sabda Allah lewat pengajaran ataupun acuan hidup.(Hastuti 2013) Gereja bisa membuat komunitas bagi keluarga. Dengan begitu keluarga dari semenjak 
BONAFIDE: Jurnal Teologi dan Pendidikan Kristen

www.jurnal.sttissiau.ac.id/Volume 1/Nomor 2/Desember 2020/hal. 218-233

pernikahan memperoleh petunjuk serta pertolongan dalam mengatur rumah tangganya.(Rantung 2019)

Berdasarkan hasil penelitian Nova Ritonga dan Djois A. Rantung menemukan bahwa pemahaman keluarga tentang PAK keluarga di GKRI jemaat diaspora Cawang Jakarta Timur sudah memadai. Evaluasi konteks (context) ditemukan bahwa pemahaman dan kesanggupan orang tua mengenai dasar PAK keluarga pada kategori kurang baik. Evaluasi masukan (input), kesiapan pendidik dan peserta didik pada kategori sangat baik (100\%). Evaluasi strategi PAK keluarga dan perencanaan dana dalam kategori sangat tidak baik.(Ritonga dan Rantung 2018) Sedangkan riset tentang implementasi PAK Konteks Gereja Di GKII Tandang, Semarang, ditemukan bahwa PAK telah dilakukan dalam jemaat gereja. Adapun bentuk-bentuk pelaksanaan PAK yaitu: pengajaran melalui khotbah dalam ibadah minggu, katekisasi, persekutuan komsel, persekutuan kategorial, ibadah padang, persekutuan doa, dan puasa.(Nuh, Darmawan, dan Sujoko 2019)

Di Gereja Masehi Injili di Timor (GMIT) Talenalain Manulai 1, khususnya jemaat rayon 5, penulis menemukan ada beberapa keluarga yang mengalami perselisihan karena hak kepemilikian harta warisan dan mengakibatan tidak ada perdamaian antar saudara selama 15 tahun sampai saat ini. Melihat kenyataan yang terjadi, maka pengajaran Pendidikan Agama Kristen diutamakan cinta kasih dan kepedulian perlu di kembangkan dalam keluarga Kristen zaman sekarang. Karena itu, penulis ingin membahas peran gereja dalam menumbuhkan perhatian, motivasi dan sikap untuk memperbaiki hubungan antar manusia. Serta 
BONAFIDE: Jurnal Teologi dan Pendidikan Kristen

www.jurnal.sttissiau.ac.id/Volume 1/Nomor 2/Desember 2020/hal. 218-233

menajamkan kembali perasaan untuk saling mengasihi dan mempedulikan melalui Pendidikan Agama Kristen keluarga di gereja yang belum berjalan dengan baik.

\section{METODE PENELITIAN}

Penulis menggunakan metode kualitatif. Metode ini dipakai untuk meneliti situasi obyek yang alami, di mana peneliti merupakan bagaikan instrumen kunci, metode pengumpulan informasi dicoba dengan cara triangulasi (kombinasi). Analisis informasi lebih pada induktif serta hasil riset kualitatif lebih menekankan arti dari pada abstraksi.(Sugiyono 2016)

Pemantauan merupakan cara pengumpulan data open-ended (terbuka) pada sumber awal dengan memantau atau mencermati orang serta tempat di sesuatu posisi penelitian. Pendekatan pemantauan ialah, mengakulasi dengan metode: melakukan pemantauan bagaikan kontestan, melaksankan pemantauan bagaikan seseorang pengamat. Pertama-tama mencermati layaknya “orang luar", setelah itu ikut serta dalam mengamati seperti “orang dalam”.(Creswell 2015) Wawancara merupakan teknik pengambilan data melalui percakapan dua orang atau lebih dengan maksud tertentu. Pemilihan sampel menggunakan teknik purposive sampling. Sampel ditentukan berdasarkan pertimbangan tertentu (Sugiyono 2018) misalnya seseorang yang dianggap paling tahu tentang masalah yang hendak diteliti, atau memiliki kekuasaan sehingga memudahkan peneliti memasuki objek/situasi sosial yang diteliti.(Wijaya 2018) Data dianalisis diolah sedemikian rupa supaya terlihat secara lebih utuh lalu ditampilkan dalam bentuk sketsa, sinopsis, matriks, dan bentuk lainnya. (Rijali 2019) 
BONAFIDE: Jurnal Teologi dan Pendidikan Kristen

www.jurnal.sttissiau.ac.id/Volume 1/Nomor 2/Desember 2020/hal. 218-233

\section{HASIL PENELITIAN}

Berdasarkan hasil penelitian yang didapatkan di lapangan mengenai penerapan Pendidikan Agama Kristen dalam keluarga ditemukan berbagai pendapat yang diberikan oleh masing-masing informan. (F.S) mengatakan bahwa ada keluarga yang berkumpul bersama dengan akur. Sebab itulah yang diajarkan oleh Tuhan Yesus (M.S). Pendapat (K.S) mengatakan bahwa karena Pendidikan Agama Kristen menjadi dasar membangun rumah tangga. Sedangkan (O.L) berpendapat bahwa agama sangat penting dan Firman Allah lebih utama. Karena dengan Firman keluarga bertumbuh (P.S). Jadi penerapan Pendidikan Agama Kristen dalam keluarga sangat diperlukan. Firman menjadi dasar dalam pembangunan rumah tangga.

Hasil penelitian mengenai bentuk Pendidikan Agama Kristen dalam keluarga, ada empat informan yang mengatakan bahwa bentuk Pendidikan Agama Kristen dalam keluarga yaitu beribadah dan satu informan lainnya (K.S) mengatakan bahwa bentuk Pendidikan Agama Kristen dalam keluarga berupa ajaran untuk memahami arti nasihat Kristen yang sebenarnya seperti sekolah minggu dan katekesasi. Menurut informan bentuk Pendidikan Agama Kristen dalam keluarga berupa ibadah dalam keluarga dan ajaran Kristen berupa sekolah minggu dan katekesasi.

Hasil penelitian mengenai penerapan Pendidikan Agama Kristen yang dilakukan dalam keluarga yakni, gereja memberi himbauan agar setiap keluarga dapat beribadah bersama. Gereja menerapkan Pendidikan Agama Kristen dengan memberi himbauan agar keluarga beribadah bersama. 
BONAFIDE: Jurnal Teologi dan Pendidikan Kristen

www.jurnal.sttissiau.ac.id/Volume 1/Nomor 2/Desember 2020/hal. 218-233

Hasil penelitian mengenai pendidikan dalam keluarga yang diterapkan yakni: (F.S) mengatakan bahwa Penddikan Agama Kristen yang diterapkan dalam keluarga yaitu; ada anggota keluarga yang mengalami hari bahagia maka kami akan mengundang keluarga kami yang lain mulai dari opa-oma sampai cucu untuk beribadah bersama. Selain itu pada hari raya natal kami keluarga akan berkumpul dan beribadah bersama, sedangkan keluarga (M.S) mengatakan bahwa Pendidikan Agama Kristen dalam keluarga diterapkan dengan mengajak keluarga untuk beribadah bersama di rumah, setiap hari minggu mengajak keluarga pergi ke gereja atau ibadah rumah tangga. Tetapi untuk beribadah di rumah kami jarang melakukannya, keluarga (K.S) menerapkan Pendidikan Agama Kristen melalui komunikasi dalam keluarga, dan keluarga. (O.L) menerapkan Pendidikan Agama Kristen dalam keluarga dengan mengajak untuk beribadah dan sharing Firman Tuhan, tetapi kami di sini jarang untuk melakukannya. Begitupun keluarga (P.S) melakukan doa bersama. Jika ada anggota keluarga yang mengalami hari bahagia maka akan diadakan ibadah syukuran. Kesimpulannya yang dipahami oleh informan bahwa penerapan Pendidikan Agama Kristen dalam keluarga yaitu berupa berkumpul bersama keluarga saat mengalami hari bahagia (ulang tahun), merayakan natal, mengajak keluarga untuk beribadah bersama di rumah, pergi ke gereja atau ibadah rumah tangga dan melalui komunikasi dalam keluarga.

Hasil penelitian mengenai penanganan konflik dalam keluarga kelima informan memiliki jawaban yang sama yakni: untuk tahun-tahun sebelumnya gereja masih melakukan pastoral, tetapi sekarang tidak ada yang dilakukan oleh 
BONAFIDE: Jurnal Teologi dan Pendidikan Kristen

www.jurnal.sttissiau.ac.id/Volume 1/Nomor 2/Desember 2020/hal. 218-233

gereja dalam menangani konflik dalam keluarga. Jadi cara gereja dalam menangani konflik dalam keluarga yaitu tidak ada pelayanan pastoral.

Oleh karena itu, keluarga merupakan lingkungan paling utama dalam melakukan pembentukan sosial kepada anak-anak, bukan hanya anak-anak tetapi seluruh anggota keluarga dapat saling belajar dari yang lain melalui interaksi satu sama lain. Dalam hal ini, gereja berperan untuk memperlengkapi orang tua dalam menerapkan nilai-nilai kristiani kepada anak-anak dan semua anggota keluarganya. Peran gereja dalam menerapkan Pendidikan Agama Kristen dalam keluarga adalah dengan memperlengkapi orang tua dalam menerapkan nilai-nilai kristiani kepada anak-anak.

\section{PEMBAHASAN}

Berdasarkan permasalahan pokok yang diangkat dalam penelitian ini, peneliti menelaah secara cermat tentang peran gereja dalam menerapkan Pendidikan Agama Kristen kepada keluarga Kristen di GMIT Talenalain Manulai 1 rayon 5.

Peran pengajaran Pendidikan Agama Kristen dalam keluarga sangatlah penting untuk di terapkan kepada keluarga Kristen saat ini, salah satunya adalah mengupayakan keharmonisan dalam keluarga, di mana Allah adalah pusat dalam pengajaran tersebut artinya Allah berotoritas terhadap seluruh segi kehidupan manusia termasuk Pendidikan Agama Kristen dalam keluarga. Karena itu, gereja memiliki peran penting dalam menerapkan Pendidikan Agama Kristen terhadap keluarga saat ini. Gereja harus mewujudkan pendidikan tersebut melalui berbagai cara dan proses agar menimbulkan pembelajaran bagi setiap anggota jemaat 
BONAFIDE: Jurnal Teologi dan Pendidikan Kristen

www.jurnal.sttissiau.ac.id/Volume 1/Nomor 2/Desember 2020/hal. 218-233

seperti ibadah bersama dan perayaan hari-hari raya gerejawi. Begitu juga dapat mendorong partisipasi jemaat, mulai dari anak-anak hingga orang dewasa dalam keseluruhan kehidupan umat Kristen, dan partisipasi keluarga dalam persekutuan bersama. Artinya gereja harus benar-benar menjalankan tugasnya dengan baik sampai jemaat memahami dan memiliki pengetahuan yang benar tentang Allah agar di dalam kehidupan setiap anggota jemaat dalam hal ini keluarga dapat hidup rukun dan harmonis. Menurut ketetapan Sinode GMIT Nomor: 03/TAP/SINGMIT/XXXIII/2015 tentang Pokok-pokok Eklesiologi GMIT, GMIT memandang bahwa keluarga Kristen merupakan basis kehidupan bergereja. Sebab itu, nilainilai kekristenan sangat penting untuk ditanamkan dan dikembangkan agar menjadi dasar kehidupan bersama.

Dalam rangka itu, keluarga Kristen perlu dibina agar mampu menjalankan kehidupan yang berkenan kepada Allah melalui tuntutan Roh Kudus. Pembinaan tersebut menyangkut nilai-nilai kekristenan yang berdasarkan kesaksian Alkitab. Berbagai persoalan keluarga seperti kekerasan dalam rumah tangga (KDRT), penjualan dan eksploitasi anak, pelecehan seksual, perselingkuhan dan berbagai persoalan lainnya, GMIT menjalankan pelayanan secara holistik dengan berbagai bentuk pembinaan kepada keluarga.

Berdasarkan hasil penelitian di atas dapat dikatakan bahwa Pendidikan Agama Kristen bagi keluarga sangat perlu untuk diterapkan dalam keluarga. Karena itu, PAK harus dilakukan dalam keluarga memberi dampak positif terhadap perkembangan anak, baik perilaku maupun spiritualitasnya.(Ritonga dan Rantung 2018) Gereja memiliki berbagai peran, tugas, dan tanggung jawab yang 
BONAFIDE: Jurnal Teologi dan Pendidikan Kristen

www.jurnal.sttissiau.ac.id/Volume 1/Nomor 2/Desember 2020/hal. 218-233

untuk mendidik warganya mengemban misi mewujudkan perdamaian.(Budiarti 2018) Pelaksanaan PAK dalam keluarga terdiri atas mezbah keluarga, keteladanan orang tua, dan pengajaran. Ketiga hal tersebut penting dijalankan karena memberikan pengaruh terhadap perilaku seluruh anggota keluarga.(La'bi' 2018) Gereja harus mengubah sikap, meningkatkan kepekaan, dan mempromosikan praktik inklusif di seluruh jemaat.(Collins dan Ault 2010)

Orangtua sangat berperan penting dalam mendidik anak-anak karena keluarga merupakan tempat pertama kali bagi anak untuk mendapatkan pendidikan sebelum mereka memasuki pendidikan sekolah. Orang tua perlu membentuk perilaku anka yang baik, agar mereka menjadi lebih dewasa dan bertanggung jawab.(Tari dan Tafonao 2019) Itu sebabnya Paulus menyerahkan tugas serta tanggung jawab ini pada ibu dan bapak. Pendidikan Agama Kristen mempersiapkan peserta didik untuk menjadi tegak secara moral dan mempengaruhi mereka untuk takut Tuhan dan hormatilah sesama manusia. Ini adalah sebuah solusi yang mungkin untuk masalah moralitas.

Bentuk Pendidikan Agama Kristen dalam keluarga menurut Informan yaitu berupa ibadah dalam keluarga dan ajaran Kristen berupa sekolah minggu dan katekesasi. Ada dua hal yang penting, yang harus dilakukan keluarga untuk mewujudkan pertumbuhan rohani keluarga, yaitu kebaktian keluarga dan saat teduh. Dengan cara efisien, gereja perlu membimbing para orang berumur wajib berperan seperti guru, yaitu pertama-tama, mereka harus membuktikan pada kanak-kanak bahwa mereka merupakan pembelajar yang suka membaca novel, senantiasa mengharapkan anak-anak mereka, memperlihatkan pengurusan 
BONAFIDE: Jurnal Teologi dan Pendidikan Kristen

www.jurnal.sttissiau.ac.id/Volume 1/Nomor 2/Desember 2020/hal. 218-233

keluarga yang baik dan mengidentifikasi perkembangan anak-anak.(Sianipar dan Kia 2018) Secara paedagogis dari segi pendidik/pengajar baik pendidik di gereja maupun di keluarga memiliki persyaratan yang sama menyangkut pengalaman rohani.(Kurniadi 2016)

Pendidikan Agama Kristen dalam ditemukan bahwa: pertama, gereja semakin bertumbuh dan berkembang. Kedua, keluarga Kristen menjadi teladan/ contoh yang baik. Ketiga, keluarga Kristen memiliki dasar kekristenan yang benar.(Gulo 2017) Orang tua meyakini bahwa anak-anak mereka membutuhkan bantuan untuk melawan oposisi dunia dan membutuhkan keselamatan. Orang tua harus berjuang melawan tantangan waktu dan cita-cita yang belum terpenuhi. Meskipun demikian tantangan perasaan orang tua dalam pengalaman, termasuk positif kenikmatan, cinta, dan kesuksesan.(Bunnell 2016)

Pendidikan agama dari semua sudut dan dari semua bidang penelitian telah menunjukkan tanpa keraguan bahwa signifikansinya pada anak-anak dan masyarakat tidak dapat diabaikan. Keagamaan Pendidikan telah terbukti menyediakan celah untuk pengembangan spiritual dalam rangka membantu siswa untuk berpikir tentang dan bertindak dalam menanggapi pertanyaan tentang makna dan fungsi dalam hidup, dan pertanyaan tentang pemandangan moral dalam masyarakat manusia; untuk mempertimbangkan dan bereaksi terhadap keindahan hidup dan seni.(Itulua-Abumere 2013) Peranan orang tua dan gereja merupakan satu kesatuan dalam membangun keluarga yang harmonis. Orang tua dapat berperan bagi anak remaja sebagai pendidik, mendidik mereka dengan 
BONAFIDE: Jurnal Teologi dan Pendidikan Kristen

www.jurnal.sttissiau.ac.id/Volume 1/Nomor 2/Desember 2020/hal. 218-233

menumbuhkembangkan nilai-nilai Kristen dalam diri mereka berdasarkan Firman Tuhan.(Wadi dan Selfina 2016)

Penerapan Pendidikan Agama Kristen oleh gereja dalam keluarga menurut para informan bahwa yang dilakukan gereja adalah memberi himbauan agar keluarga beribadah bersama. Keluarga menerapkan Pendidikan Agama Kristen dengan cara berkumpul bersama keluarga saat mengalami hari bahagia (ulang tahun), merayakan natal, mengajak keluarga untuk beribadah bersama di rumah, pergi ke gereja atau ibadah rumah tangga dan melalui komunikasi dalam keluarga, tetapi untuk melakukan ibadah dirumah, rata-rata kelima keluarga jarang untuk melakukannya. Padahal seperti dikatakan Marjorice Thompson bahwa doa pribadi tiap anggota dalam keluarga yang dilakukan tiap hari penting bagi kehidupan rohani mereka. Hal tersebut menambatkan hubungan mereka satu sama lain dengan Tuhan.(Thomson 2011)

Pendidikan yang dilakukan orang tua kepada anak-anaknya di dalam keluarga, diajarkan melalui sikap, perilaku dan perkataan dari orang tua kepada anak-anaknya secara langsung.(Munandar 2020) Orang tua harus mendidik anakanaknya dengan semangat agama yang menjunjung tinggi jati diri dan nilai-nilai seseorang. Agama adalah bentuk spiritualitas yang penting. Pengetahuan tentang nilai-nilai agama merupakan urgensi budaya yang menentukan penempatan seseorang di ruang budaya.(Ene dan Barna 2015) Meskipun penting bagi anakanak untuk menghadiri ibadah bersama orang tua mereka dan menghadiri katekese, cara orang tua bertindak sehari-hari akan mempengaruhi perkembangan 
BONAFIDE: Jurnal Teologi dan Pendidikan Kristen

www.jurnal.sttissiau.ac.id/Volume 1/Nomor 2/Desember 2020/hal. 218-233

iman anak. Orang tua perlu membahas berbagai hal iman, relevan dengan kehidupan dan keadaan anak.(Van Niekerk dan Breed 2018)

Praktik pendidik menunjukkan bahwa spiritualitas anak dipromosikan secara kebetulan dan tanpa disengaja. Ini menjadi bukti bahwa meskipun pendidik mengetahui sesuatu tentang mempromosikan spiritualitas anak, baik formasi spiritual maupun informasi tentang spiritualitas diperlukan untuk memungkinkan pendidik secara sengaja dan efektif merencanakan peluang spiritual anak.(Robinson 2017) Karena itu, keluarga memegang peranan penting dalam proses belajar PAK.

Gereja dalam menangani konflik dalam keluarga, kelima Informan mengatakan bahwa tidak ada pelayan pastoral yang dilakukan oleh gereja untuk sekarang ini. Ada beberapa upaya yang dapat dilakukan oleh PAK Gereja, yaitu: melakukan penguatan spiritualitaskeluarga melalui pesan dan narasi dalamAlkitab; melakukan pengembangan hubungan antara keluarga dengan unitunit sosial yang lebih luas.(Sianipar 2020) Kemampuan para pengajar sebagai orang yang bertanggung jawab dalam pengembangan pembelajaran PAK di gereja perlu menjadi perhatian. Kemampuan yang mumpuni menghantarkan pada hasil yang memuaskan, yaitu terciptanya bahan ajar yang berlandaskan teologi.(Ritonga 2020) Gereja yang bertumbuh adalah gereja yang menghargai pentingnya PAK serta menjalankan tugas pokok gereja dengan komitmen hubungan yang harmonis secara vertikal (Gembala/jemaat dengan Allah) maupun horisontal (antar internal jemaat dan eksternal/masyarakat).(Sihombing 2018) 
BONAFIDE: Jurnal Teologi dan Pendidikan Kristen

www.jurnal.sttissiau.ac.id/Volume 1/Nomor 2/Desember 2020/hal. 218-233

Alkitab mengamanatkan agar orang tua mendidik anak. Amanat ini adalah yang pertama dan hanya tugas wajib yang diberikan kepada orang tua, dan tidak boleh disepelekan alasan atau tugas lainnya. Tidak ada pengganti dalam hubungan manusia untuk orang tua cinta. Orang tua dapat mencari bantuan dari guru terlatih lainnya untuk membantu pada saat sibuk jadwal. Kompleksitas kehidupan telah menciptakan ruang bagi para guru untuk masuk ke dalamnya kehidupan anakanak sebagai orang tua-guru.(Maitanmi 2019)

Orang tua mengenal kepribadian anak, melatih sejak dini agar anak-anak memiliki nilai kesopanan, terbiasa dengan pekerjaan rumah, orangtua membiasakan makan bersama anak-anak, memberi pujian kepada anak-anak ketika berhasil mengerjakan tugas yang diberikan.(Imeldawati 2019) Gereja menemukan dan berlatih mengidentifikasi meredakan kecemasan dalam diri mereka sendiri, para pendeta bisa mulai dengan pelayanan di rumah.(Son 2019) Oleh karena itu gereja adalah tempat orang percaya berakar, bertumbuh dan berbuah dalam Kristus.

\section{KESIMPULAN}

Berdasarkan hasil penelitian yang dipaparkan di atas maka peneliti menyimpulkan bahwa Pendidikan Agama Kristen adalah pendidikan yang paling penting di dalam kehidupan setiap keluarga Kristen, di mana orang tua memberikan didikan bagi setiap anak. Tujuannya agar setiap keluarga Kristen tetap hidup rukun di tengah-tengah konflik yang terjadi dalam keluarga. Hal ini merupakan salah satu tanggung jawab gereja dan keluarga. Gereja bertanggungjawab menerapkan Pendidikan Agama Kristen guna membentuk nilai 
BONAFIDE: Jurnal Teologi dan Pendidikan Kristen

www.jurnal.sttissiau.ac.id/Volume 1/Nomor 2/Desember 2020/hal. 218-233

dan watak kristiani untuk melahirkan keluarga Kristen yang hidup dalam takut akan Tuhan. Ini penting untuk mengatasi persoalan atau konflik yang terjadi dalam keluarga Kristen. Selain itu, gereja harus mewujudkan Pendidikan Agama Kristen melalui berbagai cara dan proses, salah satunya mengajar yaitu melalui ibadah bersama, perayaan hari raya gereja, mengajar melalui partisipasi keluarga dalam persekutuan dan perkunjungan kepada setiap keluarga. Selain gereja, keluarga turut menerapkan Pendidikan Agama Kristen dalam keluarga masingmasing agar kehidupan mereka dapat mewujudkan kasih Allah dan dapat menyelesaikan persoalan yang terjadi dalam keluarga dengan baik.

\section{DAFTAR PUSTAKA}

Andrianti, Sarah. 2012. "Pendidikan Kristen: Keseimbangan Antara Intelektualitas dan Spiritualitas." Jurnal Antusias 2 (2): 23-48.

Budiarti, Tirsa. 2018. "Model-Model Pendidikan Perdamaian Bagi Anak Dalam Konteks Gereja." Jurnal Jaffray 16 (1): 55. https://doi.org/10.25278/ jj71.v16i1.280.

Bunnell, Peter Wayne. 2016. "Parental Involvement in Elementary Children's Religious Education: A Phenomenological Approach." Doctoral Dissertations and Projects, Mei.

Collins, Belva C., dan Melinda Jones Ault. 2010. "Including Persons with Disabilities in the Religious Community: Program Models Implemented by Two Churches." Journal of Religion, Disability and Health 14 (2): 113-31. https://doi.org/10.1080/15228961003622195.

Creswell, John. 2015. Riset Pendidikan, Perencanaan, Pelaksanaan dan Evaluasi Riset Kualitatif dna Kuantitatif. Yogyakarta: Pustaka Pelajar.

Darmawan, I Putu Ayub. 2014. "Peran Gereja dalam Pendidikan Nasional." Jurnal Simpson 1 (2): 205-16.

Eliasaputra, Mark Phillips, Martina Novalina, dan Ruth Judica Siahaan. 2020. "Tantangan Pendidikan Agama Kristen di Era Revolusi Industri 4.0 dan Pasca Kebenaran.” BONAFIDE: Jurnal Teologi dan Pendidikan Kristen 1 (1): 1-22. https://doi.org/10.46558/bonafide.v1i1.7.

Ene, Ionel, dan Iulina Barna. 2015. "Religious Education and Teachers' Role in Students' Formation towards Social Integration.” In Procedia - Social and 
BONAFIDE: Jurnal Teologi dan Pendidikan Kristen

www.jurnal.sttissiau.ac.id/Volume 1/Nomor 2/Desember 2020/hal. 218-233

Behavioral Sciences , 30-35.

Gulo, Sadiria. 2017. "Prinsip Pendidikan Agama Kristen Dalam Keluarga Bagi Keluarga Banua Niha Keriso Protestan (BNKP) Gunung Sitoli." JURNAL GLOBAL EDUKASI 3 (3): 452-56.

Harmadi, Mariani, dan Agung Jatmiko. 2020. "Pembelajaran Efektif Pendidikan Agama Kristen Generasi Milenial." PASCA : Jurnal Teologi dan Pendidikan Agama Kristen 16 (1): 62-74. https://doi.org/10.46494/psc.v16i1.72.

Hastuti, Ruwi. 2013. "Pendidikan Agama Kristen dalam Keluarga sebagai Pusat Bermisi." Antusias: Jurnal Teologi dan Pelayanan 2 (4): 48-59.

Imeldawati, Tiur. 2019. "Makna Kata Taat dan Hormat dalam Efesus 6:1-3." KERUGMA: Jurnal Teologi dan Pendidikan Agama Kristen 1 (2): 152-69.

Itulua-Abumere, Flourish. 2013. "The Significance of Religious Education in Local Primary Schools(Specific Reference to Christianity)." IOSR Journal Of Humanities And Social Science 6: 69-94. https://doi.org/10.9790/08370666994.

Kurniadi, Trisno. 2016. “Tinjauan Teologis Paedagogis Korelasi Pendidikan Agama Kristen (PAK) Gereja dan Keluarga dan Relevansinya Bagi Pelayanan Gereja Masa Kini." Manna Rafflesia 2 (2): 69-87.

La'bi', Tabita Allo. 2018. "Pengaruh Pendidikan Agama Kristen Dalam Keluarga Terhadap Perilaku Remaja Di Gereja Kemah Injil Indonesia Jemaat La'bo'.” Makassar: Sekolah Tinggi Theologia Jaffray Makassar.

Maitanmi, Stephen O. 2019. "Reflections on Christian Education." Journal of Research on Christian Education 28 (2): 91-93. https://doi.org/10.1080/ 10656219.2019.1649401.

Munandar, Aris. 2020. "Implementasi Pendidikan Kasih Di Dalam Keluarga Kristen." Veritas Lux Mea: Jurnal Teologi dan Pendidikan Kristen 2 (1): 106-20.

Niekerk, Marsulize Van, dan Gert Breed. 2018. "The Role of Parents in the Development of Faith from Birth to Seven Years of Age." HTS Teologiese Studies / Theological Studies 74 (2): 1-11. https://doi.org/10.4102/ hts.v74i2.4773.

Nuh, Semion, I Putu Ayub Darmawan, dan Edi Sujoko. 2019. "Implementasi PAK Konteks Gereja di GKII Tandang, Semarang." Pengarah: Jurnal Teologi Kristen 1 (1): 59-70. https://doi.org/10.36270/pengarah.v1i1.7.

Rantung, Djoys Anneke. 2019. "Pendidikan Agama Kristen Untuk Keluarga Menurut Pola Asuh Keluarga Ishak dalam Perjanjian Lama.” Jurnal Shanan 3 (2): 63-76.

Rijali, Ahmad. 2019. "Analisis Data Kualitatif." Alhadharah: Jurnal Ilmu Dakwah 17 (33): 81-95. https://doi.org/10.18592/alhadharah.v17i33.2374.

Ritonga, Nova. 2020. "Teologi Sebagai Landasan Bagi Gereja dalam Mengembangkan Pendidikan Agama Kristen.” Jurnal Shanan 4 (1): 21-40. 
BONAFIDE: Jurnal Teologi dan Pendidikan Kristen

www.jurnal.sttissiau.ac.id/Volume 1/Nomor 2/Desember 2020/hal. 218-233

Ritonga, Nova, dan Djoys Anneke Rantung. 2018. "Evaluasi Implementasi PAK Keluarga di GKRI Diaspora Cawang Jakarta Timur." Shanan: Jurnal Pendidikan Agama Kristen 2 (2): 107-30.

Robinson, Christine. 2017. "Educators' Practices for Promoting the Spiritual Development of Children Aged 3 to 4 Years, in the Context of Catholic Childcare Centres in Western Australia."

Sianipar, Desi. 2020. "Peran Pendidikan Agama Kristen di gereja dalam Meningkatkan Ketahanan Keluarga.” Jurnal Shanan 4 (1): 73-92.

Sianipar, Desi, dan Dan A Kia. 2018. "Analisis Impelemtasi PAK Keluarga di Gereja Sidang Jemaat Allah (GSJA) Kabupaten Barito Timur Kalimantan Tengah." Jurnal Shanan 2 (2): 37-67.

Sihombing, Yusak E.P. 2018. "Signifikansi Pendidikan Gereja Dalam Gereja Lokal." RHEMA: Jurnal Teologi Biblika dan Praktika 4 (1): 41-49.

Son, Angella. 2019. "Anxiety as a Main Cause of Church Conflicts Based on Bowen Family Systems Theory." The journal of pastoral care \& counseling : JPCC 73 (1): 9-18. https://doi.org/10.1177/1542305018822959.

Subianto, Jito. 2013. "Peran Keluarga, Sekolah, Dan Masyarakat Dalam Pembentukan Karakter Berkarakter." Edukasia: Jurnal Penelitian Pendidikan Islam 8 (2): 331-54. https://doi.org/10.21043/edukasia.v8i2.757.

Sugiyono. 2016. Memahami Penelitian Kualitatif. Bandung: Alfabeta. . 2018. Metode Penelitian Kuantitatif, Kualitatif, dan R\&D. Bandung: Alfabeta.

Tari, Ezra, dan Talizaro Tafonao. 2019. "Pendidikan Anak dalam Keluarga Berdasarkan Kolose 3:21." Kurios: Jurnal Teologi dan Pendidikan Agama Kristen 5 (1): 24-35. https://doi.org/10.30995/kur.v5i1.93.

Thomson, M.I. 2011. Keluarga Sebagai Pusat Pembentukan. Jakarta: BPK Gunung Mulia.

Wadi, Elsyana Nelce, dan Elisabet Selfina. 2016. "Peran Orang Tua Sebagai Keluarga Cyber Smart Dalam Mengajarkan Pendidikan Kristen Pada Remaja GKII Ebenhaezer Sentani Jayapura Papua." Jurnal Jaffray 14 (1): 77-92. https://doi.org/10.25278/jj71.v14i1.190.

Wahy, Hasbi. 2012. "Keluarga sebagai Basis Pendidikan Pertama dan Utama." Jurnal Ilmiah Didaktika 12 (2): 245-58. https://doi.org/10.22373/ jid.v12i2.451.

Wijaya, Hengki. 2018. Analisis Data Kualitatif Ilmu Pendidikan Teologi. Makassar: Sekolah Tinggi Theologia Jaffray Makassar. 